\title{
DEMOCRATIC LEGITIMACY BETWEEN PORT-AU-PRINCE AND CAIRO: A REPLY TO ERIKA DE WET
}

\author{
Jure Vidmar*
}

In the 1990s, international legal scholarship was marked by democratic idealism and the belief that democracy had become the only legitimate political system. ${ }^{1}$ The more radical proposals even speculated about legality of pro-democratic intervention. ${ }^{2}$ Such re-conceptualizations of international law were met with determined criticism. ${ }^{3}$ However, even skeptical voices were willing to admit that democracy nevertheless did have some limited normative force in post-Cold War international law. While it would be an exaggeration to say that nondemocratic governments are illegitimate per se, a consensus started to emerge that international law prohibited at least a coup against a democratic government. ${ }^{4}$ In the absence of a workable definition of substantive democracy for international law purposes, a democratic government was understood as an authority which comes to power in an electoral process that is reasonably free and fair.

By analyzing post-Cold War state practice predominantly in Africa but also elsewhere, Professor Erika de Wet demonstrates 5 that the norm of a coup ban was an exaggerated interpretation of the UN Security Council's responses to Haiti in $1994^{6}$ and Sierra Leone in 1997.7 According to Professor de Wet, subsequent practice in fact proves the opposite. Even after the end of the Cold War, governmental legitimacy still depends on effective control over a state territory and institutions. This argument is convincing and I agree with its central premise. In this post, I thus intend to complement Professor de Wet's proposition and further elaborate on the importance of effective territorial control for governmental representative legitimacy. Moreover, I wish to point to the rhetorical difference between the terms "coup" and "regime change," and question whether this difference has any normative underpinnings in international law.

\section{Effective Control Over a Territory}

As argued by Professor de Wet, explicit recognition of governments has declined in international practice but the concept is nevertheless present, albeit in a muted form. Namely, states indicate the acceptance or non-

* Leverbulme Early Career Fellow in the Faculty of Law and Research Fellow of St. John's College, University of Oxford.

Originally published online 20 Jan. 2015.

1 Thomas M. Franck, The Emerging Right to Democratic Governance, 86 AJIL 46 (1992).

${ }^{2}$ Fernando R. Tesón, The Kantian Theory of International Law, 92 Colum. L. Rev. 53 (1992).


BRAD R. ROTH, GOVERNMENTAL ILLEGITIMACY IN INTERNATIONAL LAW (1999).

${ }^{4}$ Jean d'Aspremont, The Rise and Fall of Democracy Governance in International Law: A Reply to Susan Marks, 22 EuR. J. INT'L LAW 549 (2011).

${ }^{5}$ Erika de Wet, From Free Town to Cairo via Kiev: The Unpredictable Road of Democratic Legitimacy in Governmental Recognition, 108 AJIL UNBOUND 201 (2015).

${ }^{6} \underline{\text { SC Res. } 940}$ (July 31, 1994).

${ }^{7}$ SC Res. 1132 (Oct. 8, 1997).

ASIL and Jure Vidmar (C) 2015 
acceptance of a certain authority by entering into relations with it or refusing to do so. Professor de Wet then takes us through the practice of denial of representative legitimacy to certain governments and argues that the principal yardstick still appears to be effective control over the state territory. At this point, I will further explore the concept of recognition of governments in contemporary international law, discuss the importance of effective control, and question how the Security Council's dealings with Afghanistan and Libya fit into the effective control framework designed by Professor de Wet.

The question of recognition or international acceptance of a new government does not arise where governments are changed in accordance with constitutional procedures. Textbooks often use the example of democratic elections. It is a central feature of constitutional democracy that an incumbent government might lose the next election and, consequently, that another authority takes control of the state. In practice, such a new government is instantly accepted by foreign governments, without any explicit recognition. However, this does not only apply to governments that come to power on the basis of a genuine electoral process. When the government of China changes, or indeed even when a new leader comes to power in North Korea, in accordance with either formal or informal internal procedures, other states ordinarily deal with the new authority and do not question the method of government formation in the foreign state. Effective control is the crucial yardstick and the 1971 China principle generally still applies: the government of the Republic of China was expelled from the Chinese seat in the United Nations because it exercised effective control over only a very small part of the Chinese territory, that is, only over Taiwan. ${ }^{8}$ The nature and democratic quality of either authority did not matter.

The problem arises, however, where both authorities can demonstrate effective control over large parts of the state, but neither one controls the territory exclusively. In this case, foreign states can indicate either by explicit recognition or implicit acceptance which authority they regard as the legitimate government of a certain state. Two caveats apply. First, the "burden of proof" is on the challenging authority (usually insurgents). Even if the incumbent government loses control over significant parts of the state territory, it will still likely be in control of the formal state apparatus. In other words, the incumbent government has the "advantage of possession". It is presumed that this is the authority in power, unless the insurgents can prove otherwise and foreign states are willing to accept an extra-constitutional change of government. Secondly, foreign states may be reluctant to accept such a change of government. Indeed, another name for this exercise may well be a coup. Professor de Wet has demonstrated that many scholars and governments argue that a coup is prohibited. How are these problems dealt with in practice of states and UN organs?

\section{Considerations Other than Effective Control}

In a set of Chapter VII resolutions, the Security Council in 2001 denied the legitimacy of the Taliban government in Afghanistan, based on grave human rights violations and threats to international peace. ${ }^{9}$ Notably, the Security Council gave its explicit support to a change of government. Despite some references to democratic principles, such as a call for a new "broad-based" government, which is "multi-ethnic and fully representative of all the Afghan people", the Taliban authority was not challenged on the basis of lacking democratic practices. ${ }^{10}$ Rather, the Security Council's measures represented a collective response to serious breaches of internationally protected human rights and involvement in international terrorism. However, the Security Council in several instances also referred to the territory of Afghanistan under Taliban control, thus

${ }^{8}$ GA Res. 2758 (XXVI) (Oct. 25, 1971).

${ }^{9} \underline{\text { SC Res. } 1267}$ (Oct. 15, 1999); $\underline{\text { SC Res. } 1333}$ (Dec. 19, 2000); SC Res. 1363 (July 30, 2001); SC Res. 1378 (Nov. 14, 2001).

${ }^{10} \underline{\text { SC Res. } 1378}$ (Nov. 14, 2001). 
indicating that the Taliban was not in control of the whole of Afghanistan. At least to some extent, the challenging of the Taliban authority was thus also based on the lack of effective control.

In 2011, the Security Council responded to the escalation of violence in Libya. Unlike the relevant resolutions on Afghanistan, the resolutions on Libya did not explicitly deny the legitimacy of the incumbent government or call for a regime change, not even when, at that time, the Benghazi-based government of the National Transitional Council was already in control of large parts of Libyan territory. Indeed, the language used in the resolutions on Afghanistan clearly denied the legitimacy of the Taliban government, while the resolutions on Libya referred to the Gaddafi government as "the Libyan authorities." 11 The authorization of the use of force was limited to the protection of the civilian population. ${ }^{12}$

It is debatable whether the international support for the National Transitional Council overstepped the Security Council's mandate, and at which point the international involvement should have stopped. However, outside of the Security Council's framework, the Libyan episode became especially interesting due to the return of a somewhat obsolete international legal concept - recognition of governments. A number of states departed from the so-called Estrada doctrine and granted explicit recognition to the National Transitional Council. ${ }^{13}$ The recognizing states clearly expressed a preference for one of the competing authorities and their decisions were rooted in human rights considerations and in a grave humanitarian situation. Indeed, for many states, the Gaddafi government lost its legitimacy by the escalation of abuses against its people.

Nevertheless, recognition of the competing authority did not come before the National Transitional Council managed to establish a degree of control over parts of the Libyan territory. In other words, governmental legitimacy was not denied to Gaddafi before he lost control over a significant part of Libya. This again indicates that regardless of how oppressive a government is, its legitimacy will not be internationally challenged as long as it is able to demonstrate effective control over the state territory.

Collective practice thus shows that foreign states may apply human rights considerations when explicitly recognizing or factually accepting a new governmental authority of another state. However, this yardstick is not applied to a firmly established effective government; it only comes into play in the circumstances of an internal power struggle where the incumbent government's effective control over the territory is in decline. This effectively means that (unelected) insurgents may be accepted as the new government. How can this be squared with the putative norm of a coup ban in international law?

Is it a Coup or a Regime Change?

Notably, the developments in Libya were generally termed a regime change, not a coup against Colonel Gaddafi. ${ }^{14}$ Likewise in Syria, international media and governments (at least Western ones) do not talk about a coup attempt against President Assad, but rather about the need for a regime change. ${ }^{15}$ "Coup" is thus seen as something negative, even prohibited under international law, while "regime change" is a least internationally tolerated, if not actively supported. Where does this difference come from?

Going back to Haiti and Sierra Leone, arguments have been made that overthrowing a democratically elected government is wrong and unacceptable. The overthrown government retains its legitimacy, even if it

$11 \underline{\text { SC Res. } 1970}$ (Feb. 26, 2011); $\underline{\text { SC Res. } 1973}$ (Mar. 17, 2011).

${ }^{12}$ Christian Henderson, II. International Measures for the Protection of Civilians in Libya and Cote d'Ivoire, 60 INT'L \& COMP. L.Q. 767 (2011).

${ }^{13}$ Dapo Akande, Recognition of Libyan National Transitional Council as Government of Libya, EJIL:TALK! (July 23, 2011); Stefan Talmon, Recognition of the Libyan National Transitional Council, 15 ASIL INSIGHTS (June 16, 2011).

${ }^{14}$ Eric Schmitt \& David E. Sanger, As Goal Shifts in Libya, Time Constrains NATO, N.Y. TimES (May 26, 2011).

${ }^{15}$ Michael Doran, Pursue Regime Change in Syria, BroOkings Institute (Jan. 23, 2014). 
is no longer in effective control. In Haiti, the Security Council even authorized the use of force to restore such a government. The difference between a coup and a regime change could thus lie in the nature of the overthrown government and, possibly, also of the challenging authority. If an overthrown government enjoys democratic legitimacy, it cannot be removed from power extra-constitutionally. This would be a coup. Yet, if it cannot claim democratic legitimacy, such a government can be ousted extra-constitutionally, especially if the challenging authority invokes its commitment to democracy and human rights. Such a scenario is called a regime change. This appears to be the coup/regime change typology in an ideal world. It follows from Professor de Wet's contribution, however, that such a typology is idealistic. An analysis of state practice shows a much messier picture.

Using democracy as a yardstick is problematic enough. Conceptually, there are problems with a definition of democracy, especially if it ought to be a normative concept of international law. If we stay with I-know-itwhen-I-see-it definition, one could certainly question the "democratic" practices of the present Libyan authorities, as well as those of the Syrian opposition. Furthermore, President Morsi of Egypt was elected and the international community nevertheless accepted his ouster. This is perhaps because a number of governments that otherwise had much (rhetorical) attachment to democracy were rather uncomfortable with Morsi's policies. Even the Ukrainian example supports the effective control premise. President Yanukovich certainly had strong opposition, but he also had strong supporters. Objectively speaking, it was difficult to determine the will of the people in Ukraine without holding free and fair elections. Yet, as soon as Yanukovich was no longer in effective control of Ukraine, it was widely accepted that he no longer had the right to act on behalf of this state. It did not matter that he was ousted extra-constitutionally. ${ }^{16}$

\section{Conclusion}

The demise of Communism and the Security Council's reaction to the situation in Haiti certainly sparked some optimism among commentators on international affairs. At the same time, it was indeed arguable that state practice was emerging in support of democratic interpretations of international law. But notable counter-practice started to emerge subsequently. Moreover, it is often forgotten that the trigger to the Security Council's involvement in Haiti was not only the coup itself but also the turmoil it created, a grave humanitarian situation, a large number of refugees, and prior UN involvement in the electoral process. It may well be that the proponents of a pro-democratic international law simply wanted to see too much in the 1994 Haiti episode. ${ }^{17}$ It is true, however, that at the time one could not have known how much counter-practice would be generated afterwards. The contribution of Professor de Wet looks back and helpfully recaptures such postHaiti counter-practice.

The representative legitimacy of governments still lies primarily in effective control over the state territory. Where control is lost at least partly, their authority may be challenged by foreign states. Human rights considerations may be a factor when foreign governments need to consider which competing authority to accept. This decision is ultimately political. In this context, a terminological difference has emerged between a coup and a regime change. In (state) practice, the use of this distinction is contradictory and unprincipled. Both terms relate to an extra-constitutional change of government. It appears that those states who disapprove the change call it a coup and those who approve of it call it a regime change. As such, the distinction cannot have any useful normative implications in international law.

16 Zachary Vermeer, Intervention with the Consent of a Deposed (but Legitimate) Government? Playing the Sierra Leone Card, EJIL:TALK! (Mar. 6, 2014).

17 Richard Falk, The Haiti Intervention: A Dangerous World Order Precedent for the United Nations, 36 HARv. INT'L L.J. 341 (1995). 
The journey from Port-au-Prince and Free Town to Cairo via Kiev thus only reaffirms that holding elections is not a panacea, neither for transitional societies nor for determining governmental legitimacy in international law. 